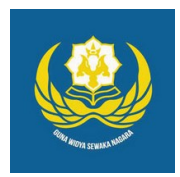

Jurnal Analogi Hukum

Journal Homepage: https://ejournal.warmadewa.ac.id/index.php/analogihukum

\title{
Wewenang Satuan Polisi Pamong Praja dalam Penegakan Peraturan Daerah Dengan Berlakunya Peraturan Pemerintah Nomor 6 Tahun 2010 di Kabupaten Badung
}

\author{
Agus Wandayuda*, I Gusti Bagus Suryawan dan I Nyoman Sutama \\ Universitas Warmadewa, Denpasar-Bali, Indonesia \\ *aguswandayuda@gmail.com
}

\begin{abstract}
How To Cite:
Wandayuda, A., Suryawan, I, G, B., Sutama, I, N. (2020). Wewenang Satuan Polisi Pamong Praja dalam Penegakan Peraturan Daerah Dengan Berlakunya Peraturan Pemerintah Nomor 6 Tahun 2010 di Kabupaten Badung. Jurnal Analogi Hukum. 2 (2). 136-141. Doi: https://doi.org/10.22225/ah.2.2.1887.136-141
\end{abstract}

\begin{abstract}
The Civil Service Police Unit is a regional apparatus organization in enforcing the Regional Regulation and holding public order as stipulated in the Republic of Indonesia Government Regulation Number 6 of 2010 concerning the Civil Service Police Unit having the authority to act in carrying out a nonjudicial order for the community or a legal entity's violation of Regional Regulations and Regional Head Regulations. The formulation of the problems that can be used for this research are: (1) What is the duty and authority of the Civil Service Police Unit in the enforcement of Regional Regulations with the enactment of Government Regulation Number 6 of 2010 in Badung Regency; (2) Any possible factors that make obstacles in the Enforcement of Regional Regulations in Badung Regency carried out by the Civil Service Police Unit. This research was conducted using normative legal research. The source and type of material of this study are primary, namely looking at legislation and secondary materia,l written by experts and the results of the scientists are then processed and analyzed descriptively to obtain a conclusion. Based on the results of the study, it can be concluded that the Satpol PP officers are part of the Regional Apparatus who carry out their duties and authorities in accordance with statutory provisions, namely in Article 148 of Law Number 23 Year 2014, that the obstacles faced by Satopl PP in Badung Regency are many shops modern people who have not fulfilled the licensing requirements in full as the provisions set by Badung Regency, so that in carrying out their duties the Satpol PP often experiences clashes with relevant agencies and the community. Suggestions given by the authors are expected to have a synergy between the Satpol PP and the relevant agencies so that in terms of enforcing regulations and order will go well so that the impression of arrogance from Satpol PP officers in carrying out their duties does not develop in the community.
\end{abstract}

Keywords: Authority, civil service police, obstacles

\begin{abstract}
Abstrak - Satuan Polisi Pamong Praja merupakan organisasi perangkat daerah dalam penegakan Perda dan menyelenggarakan ketertiban umum sebagaimana yang tertuang dalam Peraturan Pemerintah Republik Indonesia Nomor 6 tahun 2010 tentang Satuan Polisi Pamong Praja mempunyai kewenangan untuk bertindak berupaya dalam melaksanakan suatu penertiban nonyustisial bagi masyarakat atau badan hukum yang bepotensi melakukan pelanggaran atas Peraturan Daerah dan Peraturan Kepala Daerah. Rumusan masalah yang dapat dipergunakan untuk penelitian ini yaitu adalah: (1) Apa saja yang menjadi tugas dan wewenang Satuan Polisi Pamong Praja dalam penegakan Peraturan Daerah dengan berlakunya Peraturan Pemerintah Nomor 6 Tahun 2010 di Kabupaten Badung; (2) Faktor-faktor apa saja mungkin yang menjadikan kendala dalam Penegakan Peraturan Daerah di Kabupaten Badung yang dilaksanakan oleh Satuan Polisi Pamong Praja. Penelitian ini dilakukan dengan menggunakan penelitian hukum normatif. Adapun sumber dan jenis bahan penelitian ini adalah primer yaitu melihat dari perundang-undangan dan bahan sekunder tulisan para ahli dan hasil para ilmuwan kemudian diolah dan dianalisis secara deskriptif guna mendapatkan suatu kesimpulan. Berdasarkan hasil penelitian maka dapat disimpulkan bahwa petugas Satpol PP adalah bagian dari Aparatur Perangkat Daerah yang mengemban tugas dan kewenangan sesuai dengan ketentuan perundang-undangan yaitu dalam Pasal 148 UU Nomor 23 Tahun 2014, bahwa kendala yang dihadapi oleh Satopl PP Kabupaten Badung banyaknya toko-toko modern yang belum memenuhi persyaratan perijinan secara lengkap sebagaimana yang menjadi ketentuan yang telah ditetapkan oleh Kabupaten Badung, sehingga dalam
\end{abstract}


pelaksanaan tugasnya Satpol PP sering mengalami benturan dengan instansi terkait dan masyarakat. Saran yang diberikan penulis diharapkan ada sinergi antara Satpol PP dengan dinas terkait sehingga dalam hal menegakan peraturan dan ketertiban akan berjalan dengan baik sehingga kesan arogansi dari petugas Satpol PP dalam menjalankan tugasnya tidak berkembang dimasyarakat.

Kata Kunci: Wewenang, satpol PP, kendala

\section{Pendahuluan}

Pelaksanaan fungsi dari Satuan Polisi Pamong Praja (Satpol PP) di lapangan selalu menjadi topik hangat untuk di bicarakan, hal ini disebabkan Satpol PP merupakan unsur lini yang selalu terdepan dalam menjaga amanat dari Peraturan Daerah dan secara langsung selalu bersentuhan dengan masyarakat (Hasrul, 2017). Setelah Otonomi Daerah Satuan Polisi Pamong Praja menjadi Lembaga independen yang melaporkan tugas dan kewajibannya kepada Pemerintah Daerah dan memiliki kantor sendiri. Hukum (rechstaat), bukan berdasarkan kekuasaan belaka (machstaat) (Hartati, 2009).

Kedudukan Satuan Polisi Pamong Praja dalam sejarah mungkin dapat dikatakan tetap dan selalu eksis untuk menyelenggarakan Pemerintahan di Indonesia, karena Satuan Polisi pamong Praja merupakan perpanjangan tangan dari Pemerintah Kabupaten/ Kota.

Dengan dikeluarkannya Peraturan Perundang-Undangan Nomor 5 Tahun 1974 tentang suatu aturan Pokok-pokok Pemerintahan di Daerah, kemudian diganti menjadi Undang-undang No. 22 Tahun 1999 tentang Pemerintahan Daerah, selanjutnya diganti menjadi Undang-undang Nomor 32 Tahun 2004 tentang Pemerintahan Daerah dan terakhir menjadi Undang-undang Nomor 23 Tahun 2014, selalu ada peraturan dan pengaturan yang menyatakan keberadaan Satuan Polisi Pamong Praja. Peranan Satuan polisi Pamong Praja memilki tugas dan wewenang yang sangat-sangat strategis untuk meringankan kepala daerah dalam menyelenggarakan suatu kemanan dan ketertiban bagi masyarakat untuk serta dalam melakukan penegakan Perda dan Perkada lainya. Tugas Satuan polisi Pamong Praja juga dituntut untuk harus melakukan tindakan untuk mecegah hal-hal yang tidak diinginkan masyarakat dengan menegakkan kebijakan pemerintah daerah lainnya yaitu peraturan kepala daerah. Anggota Satpol PP juga memiliki tugas untuk membantu Kepala Daerah guna untuk menciptakan roda pemerintahan agar supaya berjalan dengan lancar dan masyarakat pun dapat melakukan segala kegiatannya dengan aman dan nyaman. Dari latar belakang diatas, maka dapat diambil dua buah permasalahan yaitu: 1. Apa saja yg menjadi tugas dan wewenang Satuan Polisi
Pamong Praja dalam penegakan Peraturan Daerah dengan berlakunya suatu kewenangan Peraturan Pemerintah Nomor 6 Tahun 2010 di Kabupaten Badung? 2. Faktor-faktor apa saja yang menjadi kendala dalam penegakan Peraturan Daerah di Kabupaten Badung yang dilakukan oleh Satuan Polisi Pamong Praja?

Dalam karya ilmiah hakikatnya mempunyai suatu tujuan, baik dilihat dari segi teoritis maupun segi praktisnya. Tujuan penelitian ini dapat dibagi menjadi dua yaitu, tujuan umum dari penelitian ini adalah: a. Untuk memenuhi tugas dan syarat-syarat untuk memperoleh gelar sarjana, b. Melatih diri agar dalam melaksanakan tugas masyarakat senantiasa bersikap kritis serta berpandang luas kedepan, c. Melaksanakan Tri Dharma Perguruan Tinggi bidang penelitian yang dilakukan. Dan tujuan kedua adalah Tujuan Khusus yaitu: a. Untuk dapat menjadi sumbangan ilmu pengetahuan dan pengembangan ilmu hukum khususnya pelaksanaan dan tugas wewenang Satpol PP. Untuk mencari jalan keluar bagi petugas Satpol PP dalam mengahapi kendala dalam menjalankan kewenangan.

\section{Metode}

Jenis metode penelitian yang digunakan dalam penelitian ini adalah jenis penelitian hukum normatif, dengan menggunakan acuan perundang-undangan melalui pengkajian terhadap produk perundang-undangan yang mengatur secara khusus tentang Wewenang Satpol PP dalam Penegakan Peraturan Daerah dengan berlakunya PP Nomor 6 Tahun 2010 di Kabupaten Badung.

Penelitian ini menggunakan bahan hukum primer dan sekunder. Sumber yang digunakan sebagai bahan hukum primer adalah kajiankajian hukum yang akan menjadikan ikatan yang terdiri dari: Norma dasar yaitu Peraturan Pemerintah Nomor 6 Tahun 2010 mengatur tentang Satuan Polisi Pamong Praja dan Peraturan Daerah Nomor 7 Tahun 2016 tentang tibum tranmas yaitu Ketertiban Umum dan Ketentraman Masyarakat. Sumber bahan hukum sekunder yaitu bersumber dari bukubuku. Adapun pengumpulan bahan hukum yang digunakan dalam penelitian ini adalah studi dokumentasi, yaitu membaca dan mencatat informasi penjelasan yang diperoleh dengan 
menggunakan sistem kartu, baik dari peraturan perundang-undangan maupun literatur-literatur yang memiliki kaitan dengan pokok pembahasan penelitian. Analisa hukum yang telah dikumpulkan selanjutnya diolah menggunakan logika deduktif dengan analisis interpretasi hukum dan argumentasi hukum disajikan secara deskriptif (Harahap, 2014).

\section{Hasil Dan Pembahasan}

\section{Tugas dan Wewenang Satuan Polisi Pamong Praja dalam Penegakan Peraturan Daerah dengan Berlakunya Suatu Kewenangan Peraturan Pemerintah Nomor 6 Tahun 2010 Di Kabupaten Badung}

Satpol PP sudah sangat baik dalam memberikan kontribusi yang sangat berharga bagi konsolidasi dan stabilitas sebagai tugas yang sifatnya spesifik dalam mengatasi atau menangani bidang pemerintahan umum, dan khususnya dalam pembinaan tibum tranmas yaitu ketertiban umum dan ketentraman masyarakat di daerah yang berada diluar bidang kepolisian. Dalam peningkatan kewaspadaan penyelenggaraan ketentraman dan ketertiban umum Satpol PP dituntut untuk mampu menjalin komunikasi, koordinasi dan bekerjasama sebagai langkah kewapadaan, pencegahan dini dan identifikasi terhadap setiap potensi kerawanan yang memungkinkan terjadinya suatu gangguan ketertiban umum dan ketentraman masyarakat dengan cara:

Pembinaan dan selalu berupaya dalam melakukan pemeliharaan stabilitas ketertiban umum dan ketentraman masyarakat.

Pembinaan dan kesadaran dimana akan ketaatan masyarakat dalam melakukan atau melaksanakan ketentuan Peraturan Perundang -Undangan dan Peraturan Daerah.

Selalu menjalin hubungan yang harmonis dalam melakukan kerjasama dan berkoordinasi secara fungsional dengan instansi terkait dan aparat keamanan yang lain dan masyarakat pihak terkait yang akan disesuaikan dengan segala kebutuhan berdasarkan tingkatan kerawanan yang ada di daerah sesuai dengan tugas, fungsi dan perannya sendiri-sendiri.

Satuan Kerja Perangkat Daerah yang secara khusus mempunyai kewenangan dalam penyelenggaraan ketertiban umum dan ketentraman masyarakat melalui penegakan Peraturan Daerah adalah Satpol PP. Adanya suatu kewenangan yang di perankan Satpol PP untuk menjaga ketertiban umum dan ketentraman masyarakat bukanlah tanpa alasan.
Namun, dimana didukung oleh dasar pijakan yuridis yang jelas, sebagaimana dinyatakan dalam kentuan Pasal 13 dan Pasal 14 pada huruf c Undang-Undang Nomor 23 Tahun 2014, yang menyebutkan sebagai keharusan untuk menjadi kewenangan Pemerintah Daerah dalam menyelenggarakan tibum dan tranmas.

Menjadi salah satu daerah yang otonom, Pemerintah Daerah Kabupaten Badung memiliki kewenangan untuk mengeluarkan suatu Peraturan Daerah yang bertujuan untuk menjamin dalam kepastian hukum dan menciptakan serta untuk menjaga ketentraman dan ketertiban umum. Dalam upaya penegakan Peraturan Daerah hal yang paling penting adalah di dalam pelaksanaan tugasnya di lapangan. Maka Pemerintah Daerah memiliki kewenangan untuk menunjuk Satpol PP mengambil dan Penyidik Pegawai Negeri Sipil.

Selain Undang-Undang tersebut diatas, masih terdapat perangkat hukum lain yang juga menjadi dasar kewenangan Satpol PP dalam penegakan Peraturan Daerah yaitu Peraturan Pemerintah Nomor 6 Tahun 2010 tentang satuan Polisi Pamong Praja Lembaran Negara Republik Indonesia Nomor 9 Tahun 2010, Tambahan Lembaran Negara Nomor 5096. Dimana Penerapan adanya Peraturan Pemerintah Nomor 6 Tahun 2010 merupakan penyempurnaan dari Peraturan Pemerintah Nomor 23 Tahun 2014 karena sudah tidak sesuai lagi di dalam Undang-Undang Nomor 23 Tahun 2014. Peraturan Pemerintah ini memuat pembaharuan paradigma untuk mengoptimalkan kinerja Satpol PP dalam mendukung terwujudnya suatu keadaan yang kondusif.

Dalam penegakan Perda, Petugas Satpol PP sering kali mendapatkan masalah ketika berhadapan langsung dengan masyarakat yang akhirnya menimbulkan konflik (bentrokan) antara pemerintah dengan masyarakat. Dimana dalam menghadapi masalah, Satpol PP dituntut untuk bisa memberikan solusi dan menunjukkan kinerja yang tepat sesuai dengan ketentuan yang berlaku. Polisi Pamong Praja harus menjadi petugas yang baik, ramah dan bersahabat, dimana nantinya agar terwujud situasi yang damai dan nyaman untuk masyarakat, tetap namun harus tegas dalam melakukan tindakan untuk suatu tegaknya peraturan yang ada. Oleh sebab itu maka anggota Satpol PP harus tampil profesional dalam melakukan tugasnya.

Pola-pola preventif pun harus dapat diupayakan agar dapat digunakan untuk menanggulangi potensi yang bisa memicu 
berbagai gangguan ketertiban dan ketentraman masyarakat. Adanya eksistensi Satpol PP dalam penegakan hukum yang bersifat represif yaitu dalam hal yang menyangkut pelanggaran Peraturan Daerah yang tidak bisa ditoleransi lagi contohnya sudah diberikan surat peringatan sebanyak tiga kali tetapi masih ada pelanggaran, pelaku yang melakukan pelanggaran akan ditindak secara yustisial dan non yustisial. Sebagai apparat pemerintah daerah, kontribusi Satpol PP sangat diperlukan guna untuk menjamin dan mensukseskan pelaksanaan Otonomi Daerah. Maka dari itu, diharapkan Satpol PP dapat menjadi motivator dalam menindaklanjuti dan membantu segala bentuk penyelewengan dan penegakkan hukum di tengah-tengah masyarakat serta sekaligus menjamin kepastian pelaksanaan Peraturan Daerah.

Sumber kewenangan Satpol PP adalah apparat Pemerintah Daerah yang mempunyai hak otonomi dalam penegakan Peraturan Daerah bersumber secara atribusi. Hal ini didasarkan pada pertimbangan bahwa kedudukan Pemerintah daerah bukanlah sebagai bawahan pemerintah pusat tetapi merupakan bagian dari pemerintah sebagai amanat UUD 1945.

Sebagai unsur aparatur Pemerintah Daerah selain memiliki kewenangan dalam penegakan Peraturan Daerah, Satpol PP memiliki tugas dan fungsi dalam penyelenggaraan tibum tranmas. Untuk melakukan pemahaman dimana tugas, fungsi Satpol PP, khususnya di dalam menegakkan Perda diatur dalam Peraturan Pemerintah Nomor 6 Tahun 2010 yang mana dinyatakan bahwa Satpol PP merupakan aparat daerah yang memiliki tugas dalam menegakkan Peraturan Daerah dan menyelenggarakan ketertiban umum dan ketenteraman masyarakat. Dengan diberlakukannya ketentuan ini, diharapkan dapat menjawab kesimpangsiuran tentang tugas dan fungsi dari Satpol PP.

Dengan maraknya toko-toko modern yang betepatan di Kabupaten Badung dimana tidak semua toko modern telah mengurus dan memiliki ijin toko sesuai sesuai dengan usaha yang dijalaninya, sesuai dengan Perda Kabupaten Badung Nomor 3 Tahun 2017 tentang Penataan dan Pembinaan Pasar Rakyat, Pusat Perbelanjaan dan Toko Swalayan Pemerintah Kabupaten Badung, khususnya BAB II Pasal 24 ayat (1) yang menyatakan: Pelaku usaha yang ingin melaksanakan kegiatan usahanya di bidang Pasar rakyat, Pusat Perbelanjaan dan toko swalayan diwajibkan untuk memiliki izin usaha sebagai legalitas dari Bupati .
Faktor-Faktor yang Menjadi Kendala dalam Penegakan Peraturan Daerah Di Kabupaten Badung yang Dilakukan oleh Satuan Polisi Pamong Praja

Kendala yang sering dihadapi oleh Sapol PP dalam pelanggaran yang dilakukan oleh toko modern adalah :

Dalam pengurusan ijin, ada beberapa ijin yang harus dipenuhi oleh toko modern yang belum dilengkapi tetapi sebagian dari persyaratan ijin sudah terpenuhi. Adanya beberapa persyaratan wajib yang tidak dapat dipenuhi oleh toko modern tetapi toko modern sudah beroperasi;

Dalam pengurusan ijin toko modern memerlukan banyak persyaratan yang harus dipenuhi tetapi dilapangan ada beberapa syarat perijinan sudah dimilki sehingga Satpol PP tidak bisa serta merta menutup atau mengeksekusi dilapangan karena sebagian kecil perijinan belum terpenuhi.

Sesuai dengan PERDA Nomor 7 Tahun 2016 tentang Ketertiban Umum dan Ketentraman Masyarakat Satpol PP berwenang untuk menindak toko-toko yang belum mempunyai ijin, Satpol PP dengan berkoordinasi dengan instansi terkait diantaranya Desperindag Kabupaten Badung, Dinas Perijinan Kabupaten Badung, Tim Yustisi dan dari BAPPEDA untuk melapor ke Bupati agar melakukan tindak lanjut yaitu dengan dikeluarkannya Surat Keputusan Bupati untuk menindak sesuai dengan pelanggaran yang dilakukan. Dengan langkah-langkah awal berupa sanksi administratif berupa peringatan tertulis yang berturut-turut sebanyak 3 kali dengan masa tenggang waktu selama 7 hari kerja, penyegelan/ pembekuan ijin usaha selama 3 (tiga) bulan apabila batas penyegelan tidak diindahkan akan dilakukan pencabutan ijin usaha dan untuk selanjutnya akan ditempuh tindakan pidana.

Satpol PP harus selalu berupaya dalam meletakkan fungsi kegiatan pembinaannya terhadap warga masyarakat yang dibandingkan dengan penegak hukum, sebagai usaha dalam pencegahan dimana masyarakat agar sadar terhadap hukum dan paham terhadap terciptanya keamanan.

Tugas Satpol PP semakin penting bertujuan untuk penyelenggaraan pemerintahan memiliki tugas langsung menangani penyelenggaraan ketenteraman dan ketertiban umum di wilayahnya masing-masing. Dalam rangka menegakkan Peraturan Daerah, peranan Satpol PP selain berhak melakukan 
pemeriksaan, dan dapat juga melakukan tindakan pencegahan yang bersifat non yustisial terhadap masyarakat yang melakukan suatu pelanggaran.

Peranan penting lainnya dalam merancang strategi penyelenggaraan tibum tranmas adalah dengan meningkatkan kecerdasan masyarakat melalui pelatihan-pelatihan. Hal ini sangat penting karena dengan adanya dukungan SDM yang handal, maka peluang untuk menciptakan keamanan dan ketertiban masyarakat dapat terwujud. Baik dan buruknya dari pandangan masyarakat terhadap Satpol PP, sejatinya tugas dan fungsinya untuk melakukan pembinaan keamanan, ketertiban dan penegakan hukum. Pandangan ini sangat berguna untuk di kemukakan agar terciptanya kesamaan pandangan.

Satpol PP selalu melakukan tugasnya dengan baik dan selalu memberikan kontribusi yang sangat baik bagi daerah yang memiliki penduduk yang heterogen. Adapun tugas-tugas yang dilakukan oleh Satpol PP yaitu salah satunya menangani bidang pemerintahan umum, dan khususnya dalam pembinaan tibum tranmas di daerah. Maka dari itu, kita tidak boleh memandang sebelah mata mengenai peran dan fungsi Satpol PP dalam menyelenggarakan ketertiban dan ketentraman masyarakat. Banyak masyarakat yang menganggap Satpol PP mengambil alih peran atau tugas dari POLRI dalam menegakkan peraturan.

Menurut S.P Siagian, pengawasan itu adalah salah satu proses pengamatan dari terlaksananya seluruh kegiatan organisasi dimana untuk menjamin supaya pekerjaan yang akan dilaksanakan dapat berjalan dengan aman sesuai dengan apa yang menjadi suatu tujuan nanti yang telah ditentukan (Siagian, 1990).

Demikian juga Sujatmo mengatakan pengawasan adalah segala kegiatan usaha untuk mengetahui dan menilai kenyataan yang sebenarnya mengenai pelaksanaan tugas atau kegiatan, apakah sesuai dengan semestinya atau tidak. (Sujatmo, 1996).

Dalam pengawasan diperlukan standar atau tolok ukur pengawasan sebagai bagian dari mekanisme pengawasan untuk memberikan petunjuk kepada lembaga/ aparat pengawas agar bertindak menurut peraturan yang berlaku.

Tujuan dari pengawasan adalah mengusahakan agar apa yang direncanakan menjadi kenyataan. Di sisi lain S.F Marbun mengatakan bahwa tujuan dari pengawasan itu adalah untuk mencegah timbulnya segala bentuk suatu penyimpangan-penyimpangan dan menindak atau memperbaiki segala bentuk penyimpangan yang telah terjadi (Marbun, 2001).

Secara eksplisit peranan pengawasan Satpol PP dalam keamanan dan ketertiban masyarakat diatur dalam Pasal 5 huruf $\mathrm{f}$ Peraturan Pemerintah Nomor 6 Tahun 2010 yang menyatakan yaitu pemberian pengawasan terhadap masyarakat, aparatur, atau badan hukum agar selalu sadar bahwa untuk mematuhi dan menaati Peraturan Daerah dan Peraturan Kepala Daerah. Selanjutnya dalam Pasal 1 angka 10 dinyatakan bahwa Ketertiban umum adalah suatu keadaan yang dinamis dimana dapat memungkinkan Pemerintah Daerah dan warga masyarakat untuk dapat melaksanakan kegiatan pengawasannya dengan tentram, aman, dan terpola. Satpol PP juga memiliki peranan dalam melakukan pengawasan dan ketertiban masyarakat, hal ini sesuai dengan ketentuan Pasal 14 huruf C dalam Undang-undang Nomor 23 Tahun 2014.

\section{Simpulan}

Satuan Polisi Pamong Praja Kabupaten Badung sebagai salah satu satuan kerja perangkat daerah mempunyai peranan yang sangat penting dan strategis dalam pengawasan penyelenggaraan keamanan dan ketertiban masyarakat karena dilindungi oleh peraturan perundang-udangan yang berlaku.

Kendala yang dihadapi oleh Satpol PP Kabupaten Badung pada saat melakukan tugas dan wewenangnya, dimana sering terjadinya benturan-benturan yang terjadi dikarenakan banyak toko-toko modern dalam memenuhi persyaratan perijinannya tidak sesuai dengan apa yang telah ditetapkan oleh pemerintah Kabupaten Badung, antara instansi terkait yang berwenang mengeluarkan perijinan toko modern sebagai syarat sebuah toko modern bisa beroperasi, terkadang pemilik toko modern ada juga berbuat melawan ketententuan yang berlaku sehingga Satpol PP mengalami kendala dalam mengeksekusi penutupan toko dikarenakan sering mengalami benturan baik dengan instansi terkait maupun masyarakat sekitar.

\section{Daftar Pustaka}

Harahap, M. Y. (2014). Hukum Acara Perdata. Jakarta: Sinar Grafika.

Hartati, E. (2009). Tindak Pidana Korupsi. Jakarta: Sinar Grafika. 
Hasrul, M. (2017). Eksistensi Satuan Polisi Pamong Praja Sebagai Penegak Hukum Peraturan Daerah. Amanna Gappa, 25 (2), 60-69. Retrieved from http:// journal.unhas.ac.id/index.php/agj1/ article/view/2511

Marbun, S. F. (2001). Dimensi Dimensi Pemikiran Hukum Administrasi Negara. Yogyakarta: UUI Press.

Siagian, S. . (1990). Filsafat Administrasi. Jakarta: Gunung Agung.

Sujatmo. (1996). A spek-Aspek Pengawasan di Indonesia. Jakarta: Sinar Grafika. 